Cite this: Org. Biomol. Chem., 2014, 12,108

Received 13th August 2013, Accepted 31st October 2013

DOI: 10.1039/c3ob42152j

www.rsc.org/obc

\section{A step toward polytwistane: synthesis and characterization of $C_{2}$-symmetric tritwistane $\uparrow$}

\author{
Martin Olbrich, Peter Mayer and Dirk Trauner*
}

Twistane is a classic hydrocarbon with fascinating stereochemical properties. Herein we describe a series of oligomers of twistane that converges on a chiral nanorod, which we term polytwistane. A member of this series, $C_{2}$-symmetric tritwistane, has been synthesized for the first time.
Twistane (tricyclo[4.4.0.0 $\left.0^{3,8}\right]$ decane) (1) is a tricyclic hydrocarbon that has played an important role in the development of organic stereochemistry. ${ }^{1}$ The $D_{2}$-symmetrical molecule consists of three interwoven twist boat rings, all of which have approximate $D_{2}$-symmetry with identical handedness. It can be formed, conceptually, through bridging of a cis-decalin with a single bond or by adding an ethano (ethane-1,2-diyl) bridge to a bicyclo[2.2.2]octane. In reality, twistane (1) has been synthesized numerous times, in both enantiomeric forms ${ }^{1,2}$ and as a racemate, ${ }^{3}$ starting with Howard Whitlock's seminal work in $1962 .{ }^{4}$ A large variety of substituted twistanes, including unsaturated derivatives, are now known. ${ }^{5}$

In a "Gedankenexperiment", twistane (1) can be further extended by bridging its six-membered rings with additional ethano bridges mounted in a 1,4-fashion (Scheme 1). Due to geometrical constraints, the newly formed six-membered rings continue to adopt a twist boat conformation with the same handedness as the existing rings. Provided quaternary carbons are avoided, the first substitution can only proceed in one way to yield the $C_{2}$-symmetrical ditwistane (2). Further addition of an ethano bridge to ditwistane in a linear fashion produces $C_{2}$-symmetric tritwistane (3). Linear extension of $C_{2}$-tritwistane (3) affords tetratwistane (4), pentatwistane (5), hexatwistane (6), heptatwistane (7), and so on. All of these helical compounds are chiral molecules with $C_{2}$ symmetry.

Further extension of these oligotwistanes in a linear fashion, ideally to infinity, affords a polymer with fascinating geometrical properties, which we propose to call "polytwistane" (8) (Fig. 1). Ideal polytwistane has the same molecular formula, $\mathrm{C}_{n} \mathrm{H}_{n}$, as polyacetylene but it is fully saturated with all of its $\mathrm{sp}^{3}$ hybridized carbons and hydrogens in an identical chemical

Department of Chemistry, Ludwig-Maximilians-Universität München, and Munich Center for Integrated Protein Science, Butenandtstrasse 5-13, 81377 München, Germany.E-mail: dirk.trauner@lmu.de

$\dagger$ †lectronic supplementary information (ESI) available. CCDC 948941-948947, 949955 and 949956 . For ESI and crystallographic data in CIF or other electronic format see DOI: 10.1039/c3ob42152j
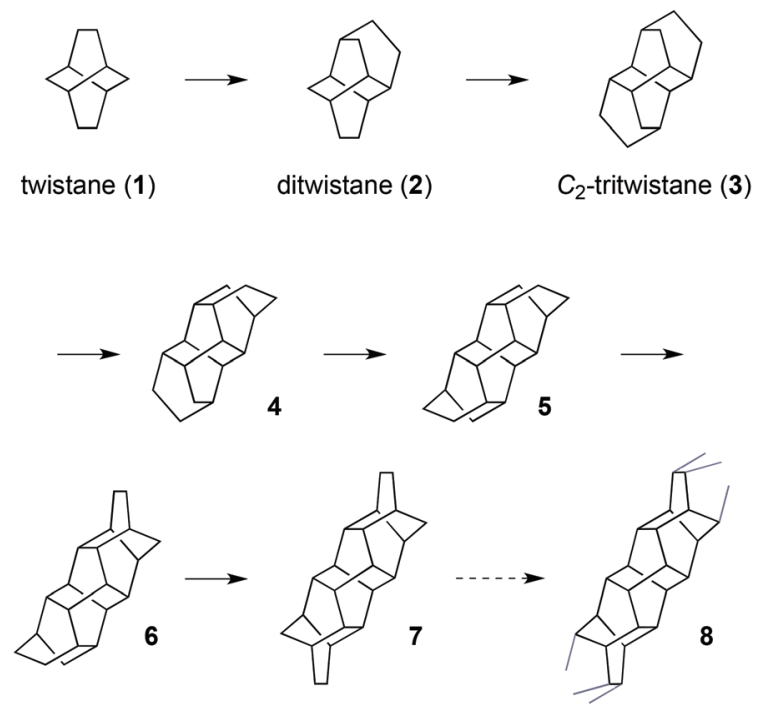

Scheme 1 Twistane (1), oligotwistanes and polytwistane (8).

environment. It is a chiral nanorod of high rigidity since none of its C,C-bonds can rotate freely and it can exist in two enantiomorphic forms, i.e. as a $P$ or $M$ helix. A more detailed description of polytwistane as a geometrical object and a prediction of its physical properties will be described elsewhere. ${ }^{6}$

Among the hydrocarbons shown in Scheme 1, only twistane (1) and ditwistane (2) are known compounds. Both enantiomers of ditwistane (2) have been synthesized ${ }^{8}$ and dozens of compounds that incorporate the ditwistane skeleton have been described. ${ }^{8}$ Structures containing the carbon skeleton of $C_{2}-$ tritwistane ${ }^{9}$ and $C_{2}$-hexatwistan ${ }^{10}$ have also been reported. None of these compounds, however, have been identified as oligotwistanes, and polytwistane (8) does not seem to have been mentioned in the literature so far.

We now report our studies on linear oligotwistanes, which were undertaken to extend the series of known oligotwistanes and obtain spectral data that might help in the identification of polytwistane. Our initial studies were based on additions to 



Fig. 1 Aspects of polytwistane (8). Top: $M$ helical polytwistane (8) drawn in a manner that emphasizes the structural unit of twistane. Middle: $M$ helical polytwistane (8) drawn in a manner that emphasizes the incorporated bicyclo[2.2.2]-octane units. Bottom: side view (left) and top view (right) of a $\mathrm{C}_{52} \mathrm{H}_{58}$-fragment of $M$ helical polytwistane calculated at the B3LYP/6-31 g(d) level. ${ }^{7}$
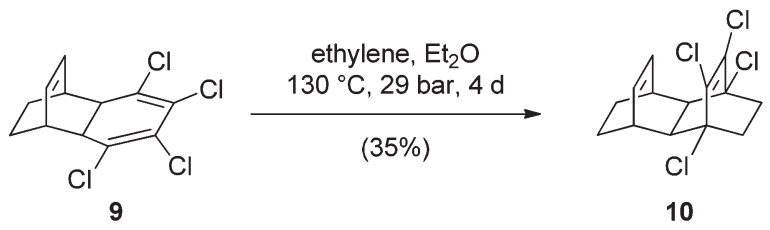

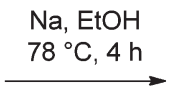

$(64 \%)$



11

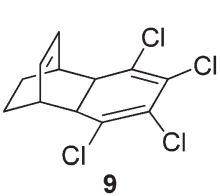

9

$\mathrm{Na}$, carbitol $\stackrel{100{ }^{\circ} \mathrm{C}, 3 \mathrm{~h}}{\longrightarrow}$

$(31 \%)$

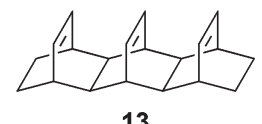

13

Scheme 2 Synthesis of the laticyclic conjugated precursors.

laticyclic polyenes, which are known to yield twistane motifs. ${ }^{10}$ To this end, we synthesized the diene $\mathbf{1 1}$ and the triene $\mathbf{1 3}$ following a strategy developed by Gleiter and colleagues (Scheme 2). ${ }^{11}$

Addition of ethylene to triene $\mathbf{9}$ at high pressure gave tetracyclic tetrachloro diene 10, which was dechlorinated to afford 11. Similarly, Diels-Alder addition of dihydrobarrelene ${ }^{12}$ to 9 gave 12, the dechlorination of which yielded the hexacyclic triene 13.

Our first attempts to synthesize tritwistane from dienes 10 or $\mathbf{1 1}$ are shown in Scheme 3. Epoxidation of tetrachloro diene $\mathbf{1 0}$ gave 14. Treatment of $\mathbf{1 4}$ with a Lewis acid in the presence of a hydride source, however, did not yield a twistane but exclusively gave 16. Presumably, this compound is the product of a "U-type" (instead of "N-type") nucleophilic attack, yielding intermediate 15, followed by an intramolecular hydride shift, as evidenced by the stereochemistry of the product $16 .{ }^{13}$
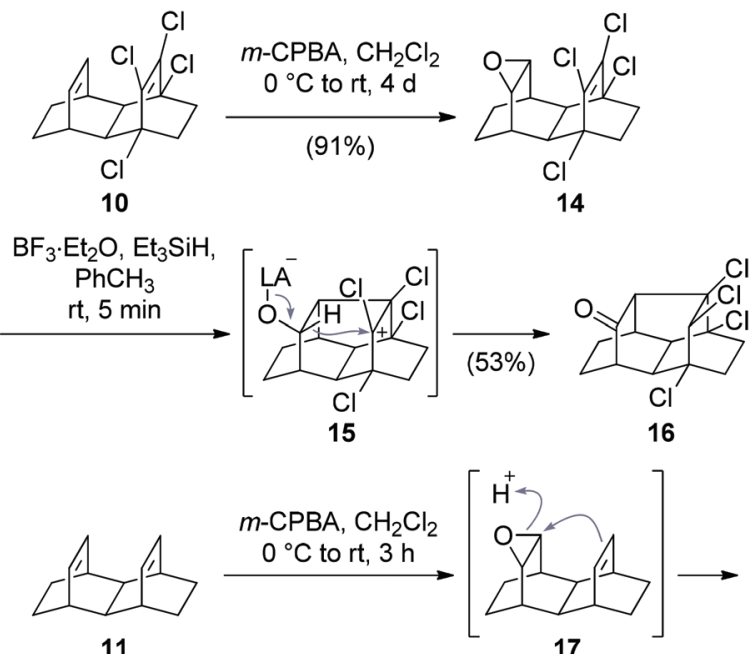

11

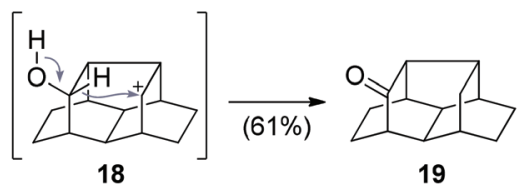

Scheme 3 Initial attempts to synthesize tritwistane via epoxidation of 10 and 11.

Epoxidation of diene $\mathbf{1 1}$ with $m$-CPBA yielded the analogous ketone 19 as the only isolable product, due to the instability of the intermediary epoxide $\mathbf{1 7}$ under the conditions. The X-ray structures of ketones 16 and 19, which bear a novel carbon skeleton, as well as epoxide $\mathbf{1 4}$ are shown in the ESI. $\dagger$

Our attempts to access the tritwistane skeleton, via halogen addition, using conditions reported by Chou and coworkers ${ }^{9}$ were more successful (Scheme 4). Exposure of tetrachloro diene 10 to bromine in chloroform gave the halogenated tritwistanes 22a,b together with the interesting syn-adduct $\mathbf{2 4}$. The former presumably stem from an "N-type" nucleophilic attack onto bromonium ion $\mathbf{2 0}$, followed by quenching of the intermediary carbocation $\mathbf{2 1}$ by bromide, which yielded a $7: 3$ mixture of diastereomers 22a and $\mathbf{b}$, respectively. The formation of 24 can be rationalized by a "U-type" nucleophilic attack, followed by an $\mathrm{S}_{\mathrm{N}}$ 2-type displacement with overall double inversion. The X-ray structures of the major diastereomer $\mathbf{2 2} \mathbf{a}$ and the syn-dibromide $\mathbf{2 4}$ are shown in Fig. 2. We next investigated the bromination on laticyclic hydrocarbon 11, which gave the dibromo tritwistane 27 as a single diastereomer, together with the unusual dibromide 30. The former is again the product of an "N-type" cyclization, whereas the latter presumably arises from a twofold Wagner-Meerwein rearrangement of the initial "U-type" cation $\mathbf{2 8}$, followed by nucleophilic interception by bromide. The X-ray structures of 27 and the rearranged $\mathbf{3 0}$ are also shown in Fig. 2.

Attempts to synthesize hexatwistane derivatives via bromination of laticyclic triene $\mathbf{1 3}$ were less successful and gave complex mixtures. So far, we have been unable to separate and cleanly characterize the major components of this mixture. Global dehalogenation of tetrachloro dibromo tritwistane 22 also failed under a variety of conditions. By contrast, 


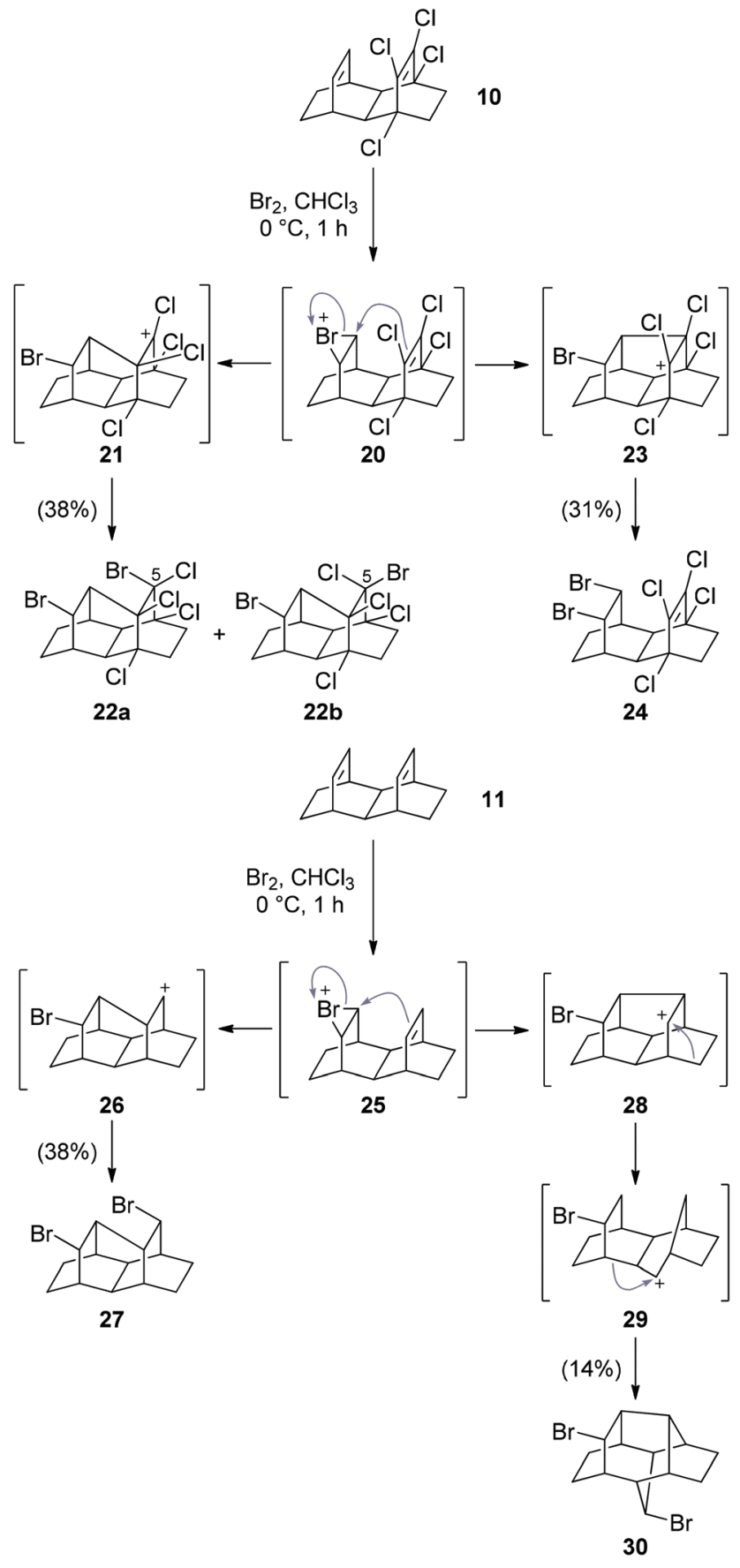

Scheme 4 Synthesis of tritwistanes 22a, b and 27 via bromination of 10 and 11.

dehalogenation of dibromo tritwistane 27 using Chatgilialoglu's reagent ${ }^{14}$ was more successful and gave the parent hydrocarbon 3 (Scheme 5). $C_{2}$-Symmetric tritwistane (3) was easy to identify due to its simplified ${ }^{1} \mathrm{H}$ - and ${ }^{13} \mathrm{C}$-NMR spectra (see $\mathrm{ESI} \dagger)$.

In summary, we have described the first synthesis of racemic tritwistane (3), which also yielded a variety of interesting byproducts. Several of these, such as compounds 16, 19 and 30, bear a novel carbon skeleton. Our results indicate that
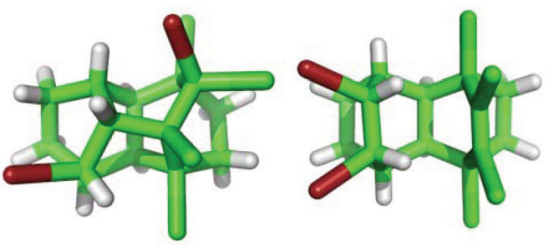

22a

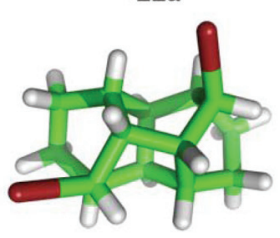

27

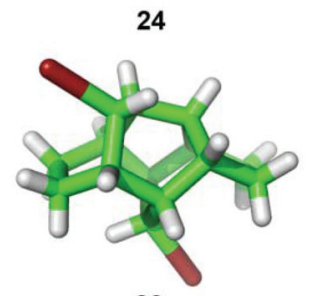

30

Fig. 2 X-ray structures of 22a, 24, 27 and 30.
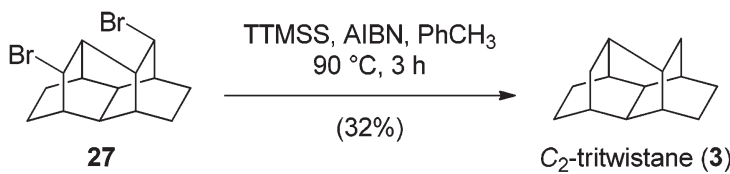

Scheme 5 Synthesis of tritwistane (3).

$\mathrm{N}$-type additions across laticyclic polyenes are not a viable way to access longer oligotwistanes or polytwistane (8) due to a variety of possible side reactions and difficulties associated with the procurement of precursors. Attempts to synthesize polytwistane in a more direct fashion from acetylene itself are ongoing in our laboratory and will be reported in due course. The relationship of polytwistane to recently reported diamond nanowires ${ }^{15}$ and ultra-small carbon nanotubes ${ }^{16}$ is also under investigation.

\section{Experimental section}

\section{Pentacyclo $\left[6.2 .2 .2^{3,6} \cdot 0^{2,7} \cdot 0^{5,9}\right]$ tetradecan-4-one (19)}

To a solution of tetracyclotetradecadiene 11 (30.0 mg, $0.161 \mathrm{mmol}, 1.00$ eq.) in $\mathrm{CH}_{2} \mathrm{Cl}_{2}(2.50 \mathrm{~mL})$ at $0{ }^{\circ} \mathrm{C}$ was added $m$-CPBA (70-75 wt $\%, 37.5 \mathrm{mg}, 0.161 \mathrm{mmol}, 1.00 \mathrm{eq}$.). The reaction mixture was stirred at $0{ }^{\circ} \mathrm{C}$ for $1 \mathrm{~h}$, was then allowed to warm to room temperature and stirred at room temperature for an additional $2 \mathrm{~h}$. After dilution with $\mathrm{CH}_{2} \mathrm{Cl}_{2}(15 \mathrm{~mL})$ the reaction mixture was poured into $10 \%$ aqueous $\mathrm{NaOH}(10 \mathrm{~mL})$ and the organic layer was washed with $\mathrm{H}_{2} \mathrm{O}(2 \times 7.5 \mathrm{~mL})$, brine $(7.5 \mathrm{~mL})$, dried $\left(\mathrm{Na}_{2} \mathrm{SO}_{4}\right)$ and concentrated in vacuo. Purification of the residue by flash column chromatography (hexanes-EtOAc $=9: 1)$ afforded ketone $19(20.0 \mathrm{mg}, 61 \%)$ as a colorless solid. Recrystallization from hexanes afforded crystals suitable for X-ray analysis.

$R_{\mathrm{f}} 0.36$ (hexanes-EtOAc $=9: 1$ ); mp $95-97{ }^{\circ} \mathrm{C} ;{ }^{1} \mathrm{H}$ NMR $\left(300 \mathrm{MHz}, \mathrm{CDCl}_{3}\right) \delta 2.80-2.71(\mathrm{~m}, 1 \mathrm{H}), 2.40-2.29(\mathrm{~m}, 1 \mathrm{H})$, 2.27-2.19 (m, 1H), 2.17-2.10 (m, 1H), 2.07-2.01 (m, 1H), 2.00-1.88 (m, 2H), 1.85-1.72 (m, 4H), 1.67-1.53 (m, 5H), 
1.52-1.37 (m, 2H); ${ }^{13} \mathrm{C}$ NMR (100 MHz, $\left.\mathrm{CDCl}_{3}\right) \delta$ 222.7, 58.9, 47.1, 42.5, 40.6, 39.1, 38.3, 37.4, 29.5, 28.6, 28.3, 27.2, 19.8, 19.8; IR $\nu_{\max }$ 2925, 2859, 1721, 1260, 1090, 1063, 1025, 994, 909, 886, 858, 812, 798, 732; HRMS (EI) $\mathrm{m} / \mathrm{z}:[\mathrm{M}]^{+}$calcd for $\mathrm{C}_{14} \mathrm{H}_{18} \mathrm{O}^{+}$202.1352; found: 202.1348 .

Bromination of $s y n-3,4,5,6$-tetracyclo $\left[6.2 .2 .2^{3,6} \cdot 0^{2,7}\right]$ tetradeca-4,9diene (11)

To a solution of diene 11 (49.9 mg, $268 \mu \mathrm{mol}, 1.00$ eq.) in $\mathrm{CHCl}_{3}(3.00 \mathrm{~mL})$ at $0{ }^{\circ} \mathrm{C}$ was added a solution of bromine in $\mathrm{CHCl}_{3}$ (1.253 mL of a 1.37 vol\% solution, $335 \mu \mathrm{mol}, 1.25$ eq.). The reaction mixture was stirred at $0{ }^{\circ} \mathrm{C}$ for $1 \mathrm{~h}$ and the reaction was then quenched by addition of diluted aqueous $\mathrm{Na}_{2} \mathrm{~S}_{2} \mathrm{O}_{3}$. The organic layer was separated and the aqueous layer was extracted with $\mathrm{CHCl}_{3}(3 \times 15 \mathrm{~mL})$. The combined organic layer was washed with $\mathrm{NaHCO}_{3}(30 \mathrm{~mL})$, brine $(30 \mathrm{~mL})$, dried $\left(\mathrm{Na}_{2} \mathrm{SO}_{4}\right)$ and concentrated in vacuo. Purification of the residue by flash column chromatography (hexanes- $\mathrm{Et}_{2} \mathrm{O}=95: 5$ ) afforded rearranged dibromide 30 (15 mg, 14\%) and dibromotritwistane 27 (35 mg, 38\%) as colorless solids. Recrystallization from hexanes afforded crystals suitable for X-ray diffraction experiments for both compounds.

5,10-Dibromopentacyclo $\left[6 \cdot 2 \cdot 2 \cdot 2^{3,6} \cdot 0^{2,7} \cdot 0^{4,9}\right]$ tetradecane (27). $R_{\mathrm{f}} 0.25$ (hexanes); ${ }^{1} \mathrm{H}$ NMR $\left(600 \mathrm{MHz}, \mathrm{CDCl}_{3}\right) \delta 4.63(\mathrm{~d}, J=$ $5.9 \mathrm{~Hz}, 1 \mathrm{H}), 4.49$ (d, $J=5.4 \mathrm{~Hz}, 1 \mathrm{H}), 2.67-2.63(\mathrm{~m}, 1 \mathrm{H})$, 2.50-2.46 (m, 1H), 2.43-2.38 (m, 1H), 2.33-2.26 (m, 1H), 2.18-2.12 (m, 2H), 2.02-1.95 (m, 2H), 1.82-1.76 (m, 2H), 1.73-1.66 (m, 2H), 1.61-1.52 (m, 2H), 1.48-1.38 (m, 2H); ${ }^{13} \mathrm{C}$ NMR (150 MHz, $\left.\mathrm{CDCl}_{3}\right) \delta 56.0,54.9,42.3,39.8,37.8,37.7$, 36.1, 35.6, 32.3, 27.5, 25.9, 21.5, 21.4, 21.2; IR $\nu_{\max } 2939,2868$, 745; HRMS (EI) m/z: [M] $]^{+}$calcd for $\mathrm{C}_{14} \mathrm{H}_{18} \mathrm{Br}_{2}^{+} 345.9750$; found: 345.9568 .

9,13-Dibromopentacyclo[6.2.2.1 $\left.1^{2,7} \cdot 1^{3,6} \cdot 0^{10,14}\right]$ tetradecane (30). $R_{\mathrm{f}} 0.35$ (hexanes); mp 130-136 ${ }^{\circ} \mathrm{C} ;{ }^{1} \mathrm{H}$ NMR (600 $\mathrm{MHz}, \mathrm{CDCl}_{3}$ ) $\delta 5.12(\mathrm{~m}, 1 \mathrm{H}), 4.78$ (ddd, $J=5.4,5.4,1.3 \mathrm{~Hz}, 1 \mathrm{H}), 2.82-2.79$ (m, 1H), 2.79-2.74 (ddd, $J=13.5,9.6,4.4 \mathrm{~Hz}, 1 \mathrm{H}), 2.52-2.46$ (m, 2H), 2.43-2.38 (m, 2H), 2.38-2.31 (m, 4H), 2.27 (dddd, $J=14.4,11.4,4.7,1.9 \mathrm{~Hz}, 1 \mathrm{H}$ ), 2.11 (dddd, $J=14.9,11.4,6.0$, $6.0 \mathrm{~Hz}, 1 \mathrm{H}), 1.83-1.76(\mathrm{~m}, 2 \mathrm{H}), 1.75-1.68(\mathrm{~m}, 1 \mathrm{H}), 1.56-1.53$ $(\mathrm{m}, 1 \mathrm{H}) ;{ }^{13} \mathrm{C}$ NMR $\left(150 \mathrm{MHz}, \mathrm{CDCl}_{3}\right) \delta 56.3,53.2,52.9,51.9$, $47.3,47.0,43.1,41.5,38.0,37.2,28.9,26.9,24.0,18.8$; IR $\nu_{\text {max }}$ 2933, 823, 803, 770, 741, 719; HRMS (EI) $m / z:[\mathrm{M}-\mathrm{Br}]^{+}$calcd for $\mathrm{C}_{14} \mathrm{H}_{18} \mathrm{Br}^{+}$265.0586; found: 265.0594.

\section{$C_{2}$-Tritwistane (3)}

To a solution of dibromide 27 (34.6 $\mathrm{mg}, 0.100 \mathrm{mmol}, 1.00$ eq.) in toluene $(3.00 \mathrm{~mL})$ was added TTMSS $(0.075 \mathrm{~mL}, 59.7 \mathrm{mg}$, $0.240 \mathrm{mmol}, 2.40$ eq.) and one crystal of AIBN (2.50 mg, $0.015 \mathrm{mmol}, 0.150$ eq.). The resulting mixture was heated to $90{ }^{\circ} \mathrm{C}$ for $3 \mathrm{~h}$ and was then allowed to cool to room temperature and was concentrated in vacuo. The residue was purified by flash column chromatography $(2 \times 20 \mathrm{~cm}, n$-pentane, $8 \mathrm{~mL})$ to afford tritwistane (3) contaminated with some silicon species as a colorless oil. A solution of this oil in $\mathrm{CDCl}_{3}$ $(1.50 \mathrm{~mL})$ was stirred over a fluoride polymer at room temperature for $8 \mathrm{~d}$. The solution was filtered over a short silica column and the solvent was removed in vacuo to afford tritwistane (3) (6 mg, 32\%) as a waxy amorphous solid.

$R_{\mathrm{f}} 0.92$ (hexanes); ${ }^{1} \mathrm{H}$ NMR $\left(600 \mathrm{MHz}, \mathrm{CDCl}_{3}\right) \quad \delta \quad 1.72$ $(\mathrm{m}, 2 \mathrm{H}), 1.70-1.63(\mathrm{~m}, 6 \mathrm{H}), 1.52-1.44(\mathrm{~m}, 10 \mathrm{H}), 1.36(\mathrm{dd}, J=$ 12.1, $5.0 \mathrm{~Hz}, 2 \mathrm{H}) ;{ }^{13} \mathrm{C} \mathrm{NMR}\left(150 \mathrm{MHz}, \mathrm{CDCl}_{3}\right) \delta 35.4,33.6$, 29.1, 28.6, 27.3, 24.8, 22.8; IR $\nu_{\max }$ 2921, 2908, 2871, 2860; HRMS (EI) $m / z:[\mathrm{M}]^{+}$calcd for $\mathrm{C}_{14} \mathrm{H}_{20}{ }^{+} 188.1560$; found: 188.1549 .

\section{Acknowledgements}

We thank the Deutsche Forschungsgemeinschaft (SFB 749) for financial support. We thank Prof. Benjamin List and Lars Winkel (MPI für Kohlenforschung, Mülheim) for assistance with high-pressure ethylene Diels-Alder reactions.

\section{Notes and references}

1 M. Tichý, Tetrahedron Lett., 1972, 13, 2001.

2 (a) K. Adachi, K. Naemura and M. Nakazaki, Tetrahedron Lett., 1968, 9, 5467; (b) M. Nakazaki, H. Chikamatsu and M. Taniguchi, Chem. Lett., 1982, 1761; (c) M. Tichý and J. Sicher, Tetrahedron Lett., 1969, 10, 4609.

3 (a) J. Gauthier and P. Deslongchamps, Can. J. Chem., 1967, 45, 297; (b) A. Bélanger, J. Poupart and P. Deslongchamps, Tetrahedron Lett., 1968, 9, 2127; (c) E. Osawa, P. v. R. Schleyer, L. W. K. Chang and V. V. Kane, Tetrahedron Lett., 1974, 15, 4189; (d) D. P. G. Hamon and R. N. Young, Aust. J. Chem., 1976, 29, 145.

4 (a) H. W. Whitlock, J. Am. Chem. Soc., 1962, 84, 3412; (b) H. W. Whitlock and M. W. Siefken, J. Am. Chem. Soc., 1968, 90, 4929.

5 (a) H.-G. Capraro and C. Ganter, Helv. Chim. Acta, 1980, 63, 1347; (b) H. Greuter and H. Schmid, Helv. Chim. Acta, 1972, 55, 2382; (c) A. Bélanger, Y. Lambert and P. Deslongchamps, Can. J. Chem., 1969, 47, 795.

6 M. Olbrich, H. Quanz, S. Barua, P. R. Schreiner, D. Trauner and W. D. Allen, Chem.-Eur. J., 2013, DOI: 10.1002/chem.201303081. 7 The Gaussian 03 reference is included in the ESI. $\dagger$

8 (a) K.-I. Hirao, T. Iwakuma, M. Taniguchi, E. Abe, O. Yonemitsu, T. Date and K. Kotera, J. Chem. Soc., Chem. Commun., 1974, 22, 691; (b) K. Hirao, T. Iwakuma, M. Taniguchi, O. Yonemitsu, T. Date and K. Kotera, J. Chem. Soc., Perkin Trans. 1, 1980, 163; (c) M. Nakazaki, K. Naemura, Y. Kondo, S. Nakahara and M. Hashimoto, J. Org. Chem., 1980, 45, 4440.

9 (a) E. LeGoff and S. Oka, J. Am. Chem. Soc., 1969, 91, 5665; (b) E. Osawa, K. Aigami and Y. Inamoto, Tetrahedron, 1978, 34, 509; (c) C.-T. Lin, N.-J. Wang, Y.-L. Yeh and T.-C. Chou, Tetrahedron, 1995, 51, 2907; (d) C.-T. Lin, H.-C. Hsu and T.-C. Chou, J. Org. Chem., 1999, 64, 7260.

10 C.-T. Lin, N.-J. Wang, H.-Z. Tseng and T.-C. Chou, J. Org. Chem., 1997, 62, 4857.

11 W. Grimme, J. Wortmann, J. Frowein, J. Lex, G. Chen and R. Gleiter, J. Chem. Soc., Perkin Trans. 2, 1998, 1893. 
12 D. A. Lightner, J. K. Gawronski and T. D. Bouman, J. Am. Chem. Soc., 1980, 102, 5749.

13 S. B. Soloway, A. M. Damiana, J. W. Sims, H. Bluestone and R. E. Lidov, J. Am. Chem. Soc., 1960, 82, 5377.

14 C. Chatgilialoglu, D. Griller and M. Lesage, J. Org. Chem., 1988, 53, 3641.
15 J. Zhang, Z. Zhu, Y. Feng, H. Ishiwata, Y. Miyata, R. Kitaura, J. E. P. Dahl, R. M. K. Carlson, N. A. Fokina, P. R. Schreiner, D. Tománek and H. Shinohara, Angew. Chem., Int. Ed., 2013, 52, 3717.

16 X. Zhao, Y. Liu, S. Inoue, T. Suzuki, R. O. Jones and Y. Ando, Phys. Rev. Lett., 2004, 92, 125502. 